\title{
The epidemic of HIV/AIDS in developing countries; the current scenario in Pakistan
}

\author{
Muhammad Z Yousaf ${ }^{1 *}$, Sadia Zia ${ }^{1}$, Masroor E Babar ${ }^{1}$ and Usman A Ashfaq ${ }^{2}$
}

\begin{abstract}
HIV (Human Immunodeficiency virus) causes (acquired immunodeficiency syndrome) AIDS, in which the immune system of body totally fails to develop any defense against the foreign invaders. Infection with HIV occurs by transfer of blood, semen, and breast milk. HIV/AIDS is a global problem and it results nearly 25 million deaths worldwide. Developing countries like Pakistan have issues regarding Public Health. Currently, epidemic of HIV/AIDS is established in Pakistan and there is a threat of an expanded HIV/AIDS outbreak in the country. The major reason is that population is engaging in high-risk practices, low awareness about HIV/AIDS, and treacherous blood transfusion practices. A supplementary threat to Pakistan is India because both sharing a border and India is facing a rapidly growing HIV/AIDS epidemic. Local NGOs, National and International organizations are warning that in near future Pakistan may experiences bad situation regarding HIV/AIDS.

In the present article we focused current situation of surveillance of HIV/AIDS, its virology, genotype, diagnostics, high-risk groups, reasons of vulnerability in Pakistani population, and the role of different national and international organizations in this situation.
\end{abstract}

\section{Background}

HIV belongs to Lentivirus, which are also known as "slow virus". The name indicates there mode of action as they enters into body and remain in it for longer period of time. They have unique property of being inserting the information into the DNA of host cell and also have the ability to replicate in non-dividing cells. Due to these characteristics they are considered to be the most efficient gene delivery vector [1]. HIV infects defense/ immune system cells such as CD4+ T cells, macrophages and dendritic cells [2]. The CD4+ cells play a crucial role in the maintenance of immune system. After infection, HIV uses CD4+ cells as host to make copies and infect other cells. This leads to the reduction of CD4+ cells in body and immune system totally collapse [3]. The development from HIV to AIDS is checked by the rapid decline of CD4+ cells [3].

\section{Types of HIV}

Two types of HIV has been characterized; HIV-1 and HIV-2. HIV-1 is the most virulent and pathogenic strain.

\footnotetext{
* Correspondence: zubairyousaf@uvas.edu.pk

'Institute of Biochemistry and Biotechnology University of Veterinary and Animal Sciences, Lahore

Full list of author information is available at the end of the article
}

Worldwide, the predominant virus is HIV-1, and generally when people refer to HIV without specifying the type of virus they will be referring to HIV-1. The relatively uncommon HIV-2 type is concentrated in West Africa and is rarely found elsewhere. The reason behind is that HIV-2 weaken the immune system slowly than HIV-1 [4]. The HIV-1 is further divided into 4-groups; a) major group M, b) Outlier group O, c) Group N, d) Group P. These groups have been identified in there envelop region. Group $\mathrm{M}$ is further divided in to $\mathrm{A}, \mathrm{B}, \mathrm{C}, \mathrm{D}, \mathrm{F}, \mathrm{G}$, $\mathrm{H}$, J and $\mathrm{K}$. in Asian countries $\mathrm{B}$ and $\mathrm{C}$ are the predominant clades of HIV-1. But in Pakistan HIV-1 is dominant in Pakistan as compare to other clades, this was found more in IDUs in Karachi [5]. HIV-2 has also 8 clades from $\mathrm{A}$ to $\mathrm{H}$, out of these clades only $\mathrm{A}$ and $\mathrm{B}$ are epidemic [6].

\section{HIV Virology and Life Cycle}

The identification of HIV led the concentrated activity in the field of molecular virology. HIV is different in structure from other retroviruses. This is roughly spherical with a diameter of about $120 \mathrm{~nm}[7,8]$. It contains three (3) structural and six (6) genes which encodes the at least fifteen (15) viral proteins and control the ability of HIV to infect the cell [9]. HIV is composed of two copies of 


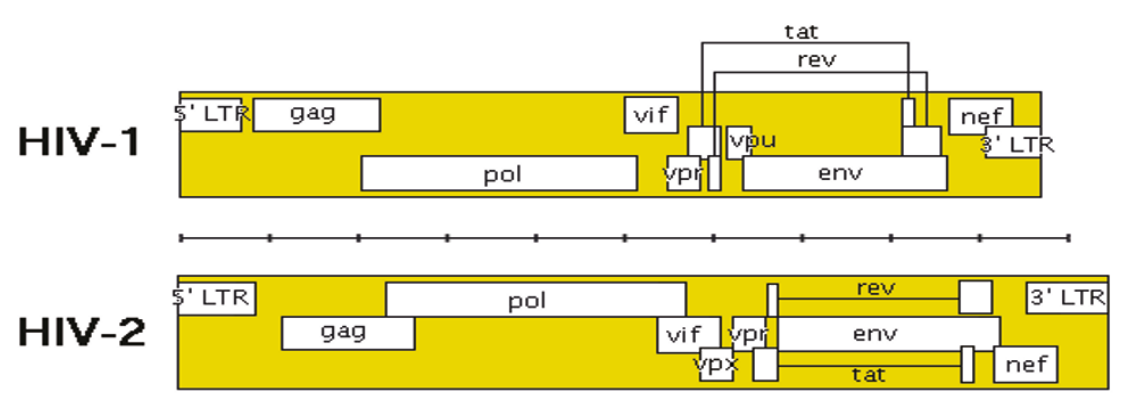

Figure 1 The diagram is based on excellent mapsof HIV-1, HIV-2 and SIV genome available at http://www.hiv.lanl.gov/content/ immunology/pdf/2000/intro/GenomeMaps.pdf.

positive single stranded RNA (Figure 1). The RNA is tightly bounded with nucleocapsid proteins and the essential enzymes for the development of virion such as; reverse transcriptase, proteases, ribonucleases and integrase [10].

The two RNAs are surrounded by the viral envelope, which is composed of phospholipids. Envelop contains embedded protein from the host cell and about 70 copies of complex HIV proteins. These proteins are called as envelop proteins or env [10]. The RNA genome consists of seven (7) genomic structural elements and nine (9) genes [11]. These are seven (7) in number including: LTR, TAR, RRE, PE, SLIP, CRS and INS. These are nine in number including; gag, pol, env, tat, rev, nef, vif, vpr, vpu and tev [11]. gag is a group specific antigen which encodes gag polyprotein. Tat is Transactivator of HIV gene expression. The env protein consists of cap made up of three molecules called glycoprotein (gp) 120, and a stem consists of gp 41 molecules that enables the virus to attach and fuse with target cells [11]. Outside the human cells, the HIV exists as roughly spherical particle. HIV particles surround them selves with a fatty material known as envelop. Nearly 72 little spikes projecting out from envelop which are formed by the gp120 and gp 41 protein (Figure 2). Below envelop there is a layer of matrix made up of protein P17. The viral capsid is usually of bullet shaped and made from the protein P24. Inside the core there are three enzymes reverse transcriptase, integrase and protease which are require for HIV replication [12].

HIV attached its life cycle by attaching the CD receptor, fuse within the cell and release its RNA into host cell. The enzyme transcriptase converts the RNA into DNA. The newly formed DNA enters the host cell nucleus and enzyme integrase hides it within the host cell's DNA. This integrated HIV DNA is called provirus, and this provirus may remain inside the body for several of years. When the provirus receives the signals to be active, they use host cell RNA polymerase to make messenger RNA [13]. The mRNA makes long chains of HIV proteins which cut with the help of proteases. The newly assembled virus pouches out from the host cell [13].

\section{Situation of Pakistan regarding HIV/AIDS}

The total population of Pakistan is 168.79 million at the end of 2009 with an average annual growth rate of 1.9\% [13]. In the ranking of most populated nations; Pakistan stands at $6^{\text {th }}$ position in the world. Pakistan is divided into four provinces viz., Punjab, Sindh, Khyber Pkahtunkhwa and Balochistan; two independent states of Azad Jammu Kashmir and Gilgit-Baltistan; and federal territories of Federal Administrated Tribal Area [FATA] and Islamabad [14]. The most populated Provinces of Pakistan are Punjab and Sindh with high HIV/AIDS prevalence. The mortality rate is 64 per 100,000 live births with life expectancy at birth of 66 years [15]. The literacy rate in Pakistan is 54\% with 0.562 human development indexes and 0.537 gender development index [16].

Pakistan is at high risk for an HIV/AIDS epidemic due to the presence of several socioeconomic conditions conducive to the spread of HIV, including poverty, low

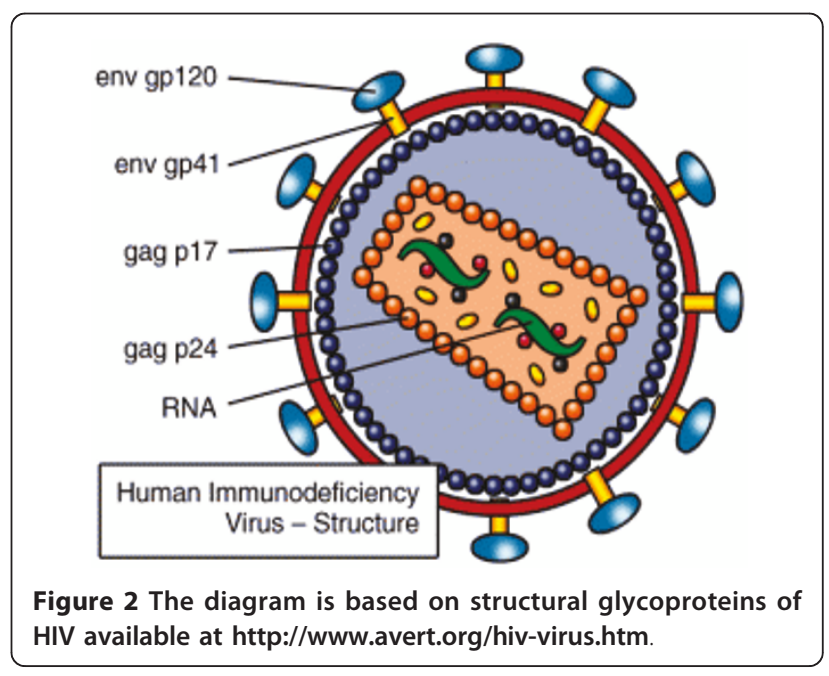


level of education and high unemployment [17]. The first case of HIV/AIDS was reported in 1987 in Pakistan. The National AIDS control Program of Government of Pakistan reports a cumulative total of 1813 HIV/AIDS cases and an estimated HIV prevalence of $0.1 \%$ as of 2001 [18]. A recent study of USAID estimated the total population of Pakistan in the mid of 2010 was 177 million with estimated population living with HIV/AIDS is 96000 at the end of 2007 [17,19], However, the reliability of available data is limited, and actual rates of HIV/ AIDS infection in Pakistan is much higher than official report suggested. The main reason is that; small number of people is registered with NGOs having HIV/AIDS. Most of them do not register them selves due to the threat of social isolation, and many of them do not aware that they are living with this disease.

\section{The Epidemic Groups}

There are 11 major core groups which are considered as high risk factors for HIV/AIDS transmission. The IDUs (intravenous injection drug users) and MSWs (male sex workers) are the main groups for HIV/AIDS in Pakistan $[19,20]$.

\section{a) IDUs and their Spouse}

In 2008 it was estimated that there are about 100,000 streets based IDUs in Pakistan of which 21\%have HIV infection [21]. According to another report the IDUs embody the core group driving the epidemic and the highest prevalence of $20.8 \%$ [22].

About 95\% of IDUs are sexually active in Pakistan and $38 \%$ have regular sexual partner [21]. The IDU's spouse are at moderate risk of acquiring HIV from their husbands via infrequent but unprotected sexual intercourse, the low condoms use and lack of HIV protection knowledge [23]. The IDUs usually go to local doctors or quakes for injections. They use the cocktail of Diazepam and Phenirimine which is readily available in Pakistani pharmacies that some times sell it without prescription [23]. The most spouse of IDUs also use drugs along with their husbands using same injections. Most of spouses were aware that they are drug users but they used to control the actual physical pain, and with the passage of time they got addicted to it.

\section{b) Male Sex workers (MSWs)}

Sex work is illegal in Islamic Republic of Pakistan, but unfortunately, it has a long history and is booming industry in the country. The most alarming thing is that, there is high rate of male to male sex in Pakistan as compare to male to female. The MSWs are more in big cities of Pakistan like Karachi, Lahore and Hyderabad. According to a survey conducted in 2007 in Rawalpindi and Abbotabad, there are 917 MSWs in these cities [24]. The MSWs are further divided in to further groups;

\section{Hijras (also known as Khusras)}

Hijras is the collective term used in Pakistan for men who are transgender, eunuch, transvestites, hermaphrodites or intersexes. Hijras are biological males who are often fully castrated (eunuch) [25]. They are respective partners in anal sex and high risk factor of HIV transmission.

\section{Zenanas and Chavas (Khotkis)}

these are the men but recognize themselves with the female gender. They depict themselves as women and commercially sell sex with multiple partners. They often married to women and have children. In sex work they assume the female gender role [26]. Chavas can switch their sexual roles.

\section{Giryas (banthas)}

these are the people who marry with Hijras and Zenanas and assume the role of husband.

\section{Maalishias}

the young and mature males work as massagers and also sell sex. Male sex workers are emerging as a second highest risk group for HIV infection after IDUs [27].

\section{c) Female Sex Workers (FSWs)}

Extrapolation of surveillance data in 2005 suggests that there are around 136,300 FSWs nationwide [28]. A study of FSWs in 8 major cities of Pakistan estimated that there were about 34,500 FSWs in these cities. These are 760 in Quetta and 14,150 in Lahore [29]. The high number of FSWs are reducing in traditional brothels and setting in residential areas and streets. Where as hotels, parlors, roadsides, chowks, chowk crossings, markets, roadsides, parks, railway stations, bus stands, mazaars, hospitals, parking are also emerging as a major assess areas for FSWs and clients in major cities [30]. The easy access to these FSWs is due to ban on Kothikhanas and dancing. They are residing among the civil society and commercial areas. These FSWs are between the ages of $13-45$ years.

\section{d) Migrant}

Migrant are those who are low skilled rural men and travel to other countries for work. They remain away from families for years and this lead them to indulge in such sexual activities. Due to unsafe sexual intercourse and they become victims of HIV/AIDS. Most of migrants are from remote areas of Punjab and tribal areas of FATA, Balochistan and Khyber Pkahtunkhwa. All the patients, who are registered in Pakistan, are those migrants who are departed back after mandatory HIV testing in abroad. The major proportion of Pakistani migrants resides in Gulf countries. Nearly 2 million people are working in 
Middle East [31]. These migrants also transmit the HIV/ AIDS to their spouse.

\section{e) Truck Drivers}

The huge population of tribal areas of Pakistan is truck drivers. They travel faraway from their houses even go to different countries adjacent to Pakistan. These truck drivers are at the high risk of acquiring and transmitting the HIV/AIDS from unprotected sex with workers and casual partners during their prolonged absence from home [31]. The sex partners of truck drivers are young boys, worked as helpers. Some times they also involve in sex with females and other male sex workers. They debut sex around 17 years, $60 \%$ are married and quarter engage in commercial and non-commercial extra martial sex and rarely use condoms [31]. The same study found $1 \%$ HIV prevalence among truck drivers in Lahore [32].

\section{f) Miners}

According to Balochistan AIDS control program there are more than 100,000 miners nationwide. They work away from their home for months. An assessment from one location found that $42 \%$ had sex with their colleagues [33].

\section{g) Prisoners}

In the year 2009 Government of Sindh has established a program for delivering HIV/AIDS prevention services to jail inmates at Karachi, Hyderabad and Sukkur. In this program inmates are informed of the threat of HIV infection and methods of prevention. They are provided access to confidential volunteer counseling and testing services for HIV/AIDS to help them know of their current HIV status. They test the prisoners from the age of 10 to 59 and above. Out of 4987 prisoners 49 were HIV/AIDS positive and most of them were IDUs [34].

\section{h) Unsafe and Invasive medical Practices}

According to World Bank report of June, 2005 Pakistan has a high rate of medical injections - around 4.5 per capita per year. Studies indicate that 94 percent of injections are administered with used injection equipment. Use of unsterilized needles at medical facilities is also widespread. According to WHO estimates, unsafe injections account for 62 percent of Hepatitis B, 84\% of Hepatitis C, and 3 percent of new HIV cases [35]. The most important thing is that; in Pakistan, the roadside dentists pose HIV threat to the people. Government of Pakistan, in 2006, figured out that there are 6,761 dentists in the country for the population of 155 million. This indicates that 1 dentist for 23,000 patients [36]. The main reasons of approaching people to these roadside unqualified doctors are; the unavailability of qualified dentists and their fee charges. The roadside dentists do not take care of hygienic issues and they use the equipments to many patients. This practice is more dangerous for spreading HIV/AIDS infection.

\section{i) Barber Shops, Beauty Saloons}

Barber is a person whose occupation is to cut any type of hair, give shaves, and trim beard. A barber differs from a hairdresser whose business is generally restricted to cutting and styling hair. Barbering is an ancient profession. The earliest records of barbers show that they were the foremost men of their tribe. Specific HIV-risks of barbering procedures relating to HIV transmission has been documented in Nigeria and other African and Asian countries [37]. The main reason for this is reuse of razors, blades and lack of awareness among barbers about HIV transmission. A recent study was conducted in 250 beauty saloons of Karachi and found that the greater risks of cuts and snips took place during manicure and pedicure. These expose areas are the greater risks for getting $\mathrm{HCV}$ and even HIV [38].

\section{j) The Transmission of HIV from Mother to Infant}

According to a estimation, there are 2.3 million children living with HIV/AIDS in the world today. The vast majority of these children are living in Asia and southern Africa. Mother to child transmission during pregnancy, childbirth, or breast-feeding is the most important source of infection in children. HIV/AIDS has not spared Pakistan, and an increasing number of women and children infected with HIV are being reported from around the country. Although the documented number of parentally acquired cases among children in Pakistan is only 40, several factors contribute to suggest that this number is a significant under-estimate. These include the lack of awareness about HIV/AIDS among the general population and among health care professionals, the stigma associated with HIV/ AIDS, lack of diagnostic testing facilities, and the difficulties of making a diagnosis in children, especially in a country where malnutrition rates are as high as $30 \%$ among children under 5 years of age [39].

\section{k) Prevalence of HIV in Pakistani Youth}

Pakistani youth just like other young people all over the world, are also curious about sex and drugs. During adolescent age of formation of values and habits, they are heavily influenced by their peers. Another study of National AIDS control program in 2005 suggested that only in Karachi streets children debut sex around the age of $13-15$ years and $30 \%$ had sold sex to men and women [40]. About $80 \%$ of them do not use condom and if they used it the decision was made by elder partner [40]. The reasons behind this bitter reality are unemployment, easy availability of narcotic drugs, economic frustration that influence the young people to engage in unsafe behavior 
which may put them at increased risk of HIV infection [41].

\section{Diagnosis Methods of HIV/AIDS in Pakistan}

NACP (National AIDS Control Program) has been involved in gigantic task of limiting the spread of HIV/ AIDS in Pakistan [42]. In Pakistan the main purpose of HIV testing is to guide the NGOs, Private and Government Hospitals and the other people that how to deal with HIV/AIDS patients [43]. There are different methods to diagnose HIV/AIDS in different research institutes and hospitals in Pakistan. The most commonly used methods include molecular and serological detections. The standard of testing people with different ages which is practiced in Pakistan is as followed;

\section{Less than 18 months of age}

The newborns of HIV infected mothers are more suspected to have this infection. These newborns are tested from 6 weeks after birth through PCR. Antibody tests can be used from 12 months for screening out the HIV negative children but the results are not supposed to be accurate because at this age most infants lost the maternal antibodies and the positive result on ELISA test usually indicate HIV infection [43].

\section{8 months of age up to 12 years}

At this stage usually ELISA or Western Blot is used to detect the HIV/AIDS. Those children who are more than 18 months and still being breastfed should cease breast feeding abruptly before testing with antibody test. But this test should be repeated after 6 weeks of cessation of breast feeding [43].

\section{Counseling of Children under 12 years of age}

The counseling process is very much important before and after the test of children. If the children are not mature enough they are counseled in the presence of parents.

\section{Diagnostics Centers for HIV/AIDS in Pakistan}

The two most common techniques for HIV/AIDS testing are available at different institutes of Pakistan under the Governance of National AIDS Control Program Pakistan.

The facility is available at Pakistan Institute of Medical Sciences (PIMS) Islamabad and Armed Forces Institute of Pathology (AFIP) Islamabad, Shaukat Khanam Memorial Hospital Lahore, Sindh Institute of Urology \& Transplants (SUIT) and Agha Khan Hospital Karachi.

The facility of ELISA is available at every tertiary care hospital including; Service Hospital, Mayo Hospital and Shaukat Khanam Hospital of Lahore. HIV Treatment
Center DHQ, Sargodha, Sindh AIDS Control Program; Indus Hospital; Agha Khan Hospital of Karachi, Bolan Medical Complex, Quetta and Hayatabad Medical Complex, Peshawar [43].

The Reasons of High Vulnerability of HIV/AIDS in Pakistan Although, HIV/AIDS prevalence appears to be low in Pakistan but there is need to establish some more accurate action plans for this. In Pakistan, the social structure and conditions include widespread poverty, significant power imbalance between men and women, low level of education, and challenges in the areas of government and human rights [44].

w? >a) Poverty is a major development concern in Pakistan, and this is also a major facilitating factor in spread of HIV. Recent documentation suggests that poverty is increasing in Pakistan, about 36 million people living below the poverty line. The poor suffer not just limitations in income; they also lack basic facilities and amenities which allow for a full and meaningful existence.

b) Gender Inequalities may also play a significant role in the further spread of HIV/AIDS in Pakistan. Pakistani women in general have lower socioeconomic status, less mobility and less decision-making power than Pakistani men, all of which contributes to their vulnerability to HIV. Because of gender disparities in educational enrollment, the $35 \%$ of women are literate as compared to $59 \%$ of men in Pakistan.

c) Other Reasons against this backdrop of poverty, gender inequalities, and low literacy rate. The general public in Pakistan is vulnerable to HIV/AIDS due to several other common behavioral patterns and risk situations. For example, rarity of condom usage, unhygienic conditions and unsafe medical practices.

\section{Suggestions and Recommendation}

While the current HIV levels are low in Pakistan but there is need to act to much avert a much larger epidemic in future. Based on all studies and findings and National and International reports by NGOs we recommend some important facts;

\section{a) General Awareness and Behavioral Change}

There is need to change the behavior of people in there daily life routine. People should be educated through radio, TV, newspapers, seminars and health related workshops about the importance of hygiene in there lives. We should facilitate the people through proper channels that they are important and there lives are more valuable like any other 
healthy person in Pakistan. There is need to target the vulnerable groups for there proper counseling.

\section{b) Ensure the Safe Public Health Care Practices}

This is true as a developing country Pakistan is facing immense problems relating to public health. The poor hygiene conditions in hospitals, easy availability of drugs without any prescription from pharmacies all these are the hot issues. But still to fight against HIV/AIDS these areas should be critically checked by Government agencies and non-governmental organizations. The rate of "Atties"are also very high in rural areas of Pakistan, who do not use any sterilized equipments during there treatment. These should be ban so that the risk factor can be reduced.

\section{c) Sexual Health Care Centers}

Like other developed countries there should be sexual health care centers and rehabilitation centers in Pakistan. These centers should work along the governmental and non-government organizations in red areas of Pakistan where rate of HIV/AIDS victims are more. These centers should register those victims and provide them not only physical treatment but also mental treatment. The big hurdle in Pakistan is that people are not ready to register themselves as HIV/AIDS victims because of social pressure and died. These centers should aware the people about the safe sex practices with their partners and use of condoms.

\section{d) Say "No" to stigmatization barrier}

People here in Pakistan are drive by there social status. The people who are living below the poverty line are more stressed, frustrated and more conscious about there livelihood. If these people involved in such activities than, they face the social stigma and remain hidden. There is need to educate the people that HIV/ AIDS may not be treatable but if they are suffering with it, they are not thought to be isolated from rest of the society. Because there stigma can cause more problems for other people and can increase the risk of prevalence of HIV/AIDS in Pakistan.

\section{e) HIV study centers}

The Government of Pakistan should take initiative along with NGOs in the establishment of HIV study centers. These centers should be design district wise. The centers should be assigned with the tasks to register the HIV victims in their respective districts. These centers must collaborate with research institutes so that, the constructive work should embark on with reference to Pakistan.

\section{Conclusion}

This is the common thought in the minds of Pakistani people that as an Islamic Republic, Pakistan is protected from HIV/AIDS. This is true that Islam is against premarital sex or extra-marital sex and also homosexuality, and this is a valuable barrier against HIV/AIDS. But still there is a threat of prevalence of this disease in Pakistan.

The HIV/AIDS counseling and testing is the best way to prevent this disease in Pakistan. There should be availability and accessibility of antiviral treatment so that people suffering with HIV can enjoy better life. The government of Pakistan should play there role because the successful and comprehensive HIV prevention program needs political leadership as this will be very much helpful is political personalities talk about HIV/AIDS on public places. This is eleventh hour to take measures against this disease to save future of Pakistan.

\section{Abbreviations \\ HIV: Human Immunodeficieny Virus; AIDS: Acquired Immunodeficiency Syndrome.}

\section{Acknowledgements}

Financial support by Higher Education Commission, Pakistan is highly acknowledged.

\section{Author details}

${ }^{1}$ Institute of Biochemistry and Biotechnology University of Veterinary and Animal Sciences, Lahore. 'Division of Molecular Medicine, National Centre of Excellence in Molecular Biology, University of the Punjab, Lahore, Pakistan.

\section{Authors' contributions}

MZY conceived the study and drafted the manuscript. SZ searched the literature and helped in manuscript write-up. MEB and UAA critically review the manuscript. All authors read and approved the final manuscript.

Authors' Information

Muhammad Z Yousaf (PhD Molecular Biology), Masroor E Babar (Director IBBT, UVAS), Usman A Ashfaq (PhD Molecular Biology), Sadia Zia (M-Phil Scholar)

\section{Competing interests}

The authors declare that they have no competing interests.

Received: 17 June 2011 Accepted: 12 August 2011

Published: 12 August 2011

\section{References}

1. BCM vector developing Laboratories. [http://vector.bcm.tmc.edu/ Lentivirus/Lentivirus_Vectors.htm].

2. Health News, First Target cells of HIV identified. [http://www.healthlibrary. com/news779.htm].

3. What is HIV. [http://hiv.boehringer-ingelheim.com/com/HIV/About_HIV/ Basics/What_is_HIV.jsp]

4. HIV types, groups and subtypes. [http://www.avert.org/hiv-types.htm].

5. Saeed Khan, Rai Mohammad, Mohammad Khanani, Muhammad Khan, Syed Ali: HIV-1 subtype A infection in a community of intravenous drug users in Pakistan. BMC 2006, 06:1-164.

6. Santiago ML, Range F, Keele BF, Li Y, Bailes E, Bibollet-Ruche F, Fruteau C, Noe R, Peeters M, Brookfield JFY, Shaw GM, Sharp PM, Hahn BH: Simian Immunodeficiency Virus Infection in Free-Ranging Sooty Mangabeys (Cercocebus atys atys) from the Tai Forest, Cote d'Ivoire: Implications for 
the Origin of Epidemic Human Immunodeficiency Virus Type 2. Journal of Virology 2005, 79(19):12515-27.

7. McGovern SL, Caselli E, Grigorieff N, Shoichet BK: A common mechanism underlying promiscuous inhibitors from virtual and high-throughput screening. J Med Chem 2002, 45(8):1712-22.

8. Lippincott's Illustrated Reviews Series: Microbiology.Edited by: Richard A Harvey. Hagerstone, MD; , 2 2007:03.

9. HIV and AIDS: 20 years of science: Molecular Virology and Epidemiology. [http://www.medscape.com/viewarticle/458523_3].

10. HIV Sequence Compendium. 2008 [http://www.hiv.lanl.gov/content/ sequence/HIV/COMPENDIUM/2008/frontmatter.pdf].

11. HIV sequence database. [http://www.hiv.lanl.gov/content/sequence/HIV/ MAP/landmark.html], Federal Bureau of Statistics, Government of Pakistan [http://www.statpak.gov.pk/fbs/content/pakistan-statistical-year-book-2010].

12. Federal Ministry of Information and Broadcasting, Islamabad, Government of Pakistan. [http://www.infopak.gov.pk/profile.aspx ].

13. UN Population Division Annex 2009. 2009 [http://esa.un.org/unpd/wup/ Documents/WUP2009_Highlights_Final.pdf].

14. UN Population Division Report 2009, Pakistan. [http://www.undp.org.pk/ 7thissue/more/HDR\%20launch\%20in\%20Pakistan.pdf].

15. USID HIV/AIDS Health Profile Pakistan. [http://www.usaid.gov/our_work/ global_health/aids/Countries/asia/pakistan_profile.pdf].

16. Together We Can, UNAIDS. 2001 [http://data.unaids.org/Publications/RCpub02/jc594-togetherwecan_en.pdf].

17. USID HIV/AIDS Health Profile Pakistan. [http://www.usaid.gov/our_work/ global_health/aids/Countries/asia/pakistan_profile.pdf].

18. National AIDS Control Program, HIV/AIDS Surveillance Project. 2005 [http://www.nacp.gov.pk/library/reports/Surveillance\%20\&\%20Research/HIVAIDS\%20Surveillance\%20Project-HASP/HIV\%20Second\%20Generation\% 20Surveillance\%20in\%20Pakistan\%20-\%20Round\%201\%20Report\%20-\% 202005.pdf ].

19. National AIDS Control Program, HIV/AIDS Surveillance Project, Round III. 2008 [http://www.nacp.gov.pk/library/reports/Surveillance\%20\&\% 20Research/HIV-AIDS\%20Surveillance\%20Project-HASP/HIV\%20Second\% 20Generation\%20Surveillance\%20in\%20Pakistan\%20-\%20National\%20report \%20Round\%20111\%202008.pdf].

20. United Nation General Assembly Special Session on HIV/AIDS Pakistan. 2010 [http://www.nacp.gov.pk/library/reports/Global\%20Reporting\% 20Documents/UNGASS\%20pakistan\%20report-2010.pdf ].

21. Ahmad S, Mehmood J, Awan BAhmad, Tariq Zafar, Kaveh Khushnood, Adnan AKhan, female Spouses of IDUs in Pakistan: A bridge population of the HIV epidemic. EMHJ 2009, 17:04.

22. HIV in Pakistan: Preventing a future epidemic in most at risk groups. [http://www.nacp.gov.pk/library/reports/Global\%20Reporting\% 20Documents/UNGASS\%20pakistan\%20report-2010.pdf ].

23. Jami h: Condition and status of Hijras (Transgender, Transvestites etc) in Pakistan, in Ist international conference of Asian Queer Studies. 2005 [http://bangkok2005.anu.edu.au/papers/Jami.pdf].

24. Sex and HIV in Pakistan. [http://www.plri.org/sites/plri.org/files/ sex_work_hiv_pakistan\%5B1\%5D.pdf].

25. Altaf $A, A b b a s ~ S$, Zaheer $H A$, Men who have sex with men: New emerging threat of HIV/AIDS spread in Pakistan. Pak Med 2008, 58(8):419-420.

26. Khan AA, Khan A, Bokhari A: the HIV epidemic in Pakistan. Pak Med 2005, 60(4):300-307.

27. Blanchard J, Khan A, Bokhari A: Variations in the population size, distribution and client volume among female sex workers in seven cities of Pakistan, Sex Transm infect. 2008, 84:24-27.

28. NACP,Mapping Networks of FSWs in Kothikhana and Private Homes,2007.National AIDS control program. [http://www.plri.org/sites/plri. org/files/sex_work_hiv_pakistan\%5B1\%5D.pdf].

29. Adnan AKhan, Ayesha Khan: The HIV epidemic in Pakistan. Pak Med 2010, $60: 4$.

30. National AIDS control Program, The Family Health International, The Pakistan Medical and Research Council. The National Study of Sexual and Reproductive Tract Infections. 2004

31. Balochistan AIDS Control, Mapping of High Risk and Bridge Groups in Balochistan. 2007.

32. Salman Safdar, Mehmood Arshad, Abbas Qamar Syed: Prevalence of HIV/ AIDS among jail inmates in Sindh, 2009. Pak Med 2009, 59:02.
33. Preventing HIV/AIDS in Pakistan, The World Bank report of 2005. [http://www.worldbank.org.pk/WBSITE/EXTERNAL/COUNTRIES/SOUTHAS IAEXT/PAKISTANEXTN/0,"contentMDK:20154303 pagePK:141137 pi PK:141127 theSitePK:293052,00.html].

34. Roadside dentist pose HIV in Pakistan. [http://www.irinnews.org/Report. aspx?Reportld=74330].

35. Arulogun SOyedunni, Adesoro OMoses: Potential risk of HIV transmission in barbering practice among barbers in Ibadan, Nigeria. 2009, 9:01.

36. Pedicure may not look drop dead gorgeous if it kill you. [http://tribune. com.pk/story/148370/sharing-instruments-that-pedicure-may-not-look-dropdead-gorgeous-if-it-kills-you/].

37. Prevention of Mother to child Transmission of HIV in Pakistan. 2006, related:http://www.nacp.gov.pk/policies_and_guidelines/ treatment_and_care/.

38. National AIDS control program, UNICEF. Situational analysis of adolescents in 10 districts of Pakistan. 2005.

39. National Youth Shadow Report Pakistan. [http://www.youthaidscoalition. org/docs/Pakistan.pdf].

40. National AIDS control Program Referral Lab. [http://www.nacp.gov.pk/ referral_lab/].

41. HIV testing criteria for children affected by HIV/AIDS. [http://www.nacp. gov.pk/policies_and_guidelines/referral_lab/Testing\%20Criteria.pdf].

42. United Nation Statement on HIV in Pakistan. [http://aidsdatahub.org/en/ pakistan-reference-materials/doc_download/2596-united-nations-statementon-hivaids-in-pakistan].

43. The Ntional HIV/AIDS Strategic Frame Work. [http://un.org.pk/unaids/ documents/National\%20HIV-AIDS\%20Strategic\%20Framework\%20(2001-06). pdf].

44. Economic Survey, Government of Pakistan 1999-2000. [http://www. paksearch.com/Government/STATISTICS/Survey00/Survey2000.html].

doi:10.1186/1743-422X-8-401

Cite this article as: Yousaf et al:: The epidemic of HIV/AIDS in developing countries; the current scenario in Pakistan. Virology Journal $20118: 401$.

\section{Submit your next manuscript to BioMed Central and take full advantage of:}

- Convenient online submission

- Thorough peer review

- No space constraints or color figure charges

- Immediate publication on acceptance

- Inclusion in PubMed, CAS, Scopus and Google Scholar

- Research which is freely available for redistribution

Submit your manuscript at www.biomedcentral.com/submit
Ciomed Central 